\title{
A PLUTONIC DIORITE COMPLEX IN THE NORTH OF THE FISKEN ESSET REGION
}

\author{
W. R. Fitches
}

\section{Introduction}

A thick diorite-monzodiorite sheet over $2 \mathrm{~km}$ in length and up to $600 \mathrm{~m}$ in width (fig. 35 ) is exposed at $50^{\circ} 25^{\prime} \mathrm{E}$ and $63^{\circ} 55^{\prime} \mathrm{N}$, about $7 \mathrm{~km}$ south of Qeqertaussaq by Kangerdluarssúngûp taserssua. Several diorite dykes, some over $10 \mathrm{~m}$ in thickness, lie parallel to the main body and up to $300 \mathrm{~m}$ from it. The north-east end of the body is covered by superficial deposits whilst the south-west part has not yet been mapped out. This is therefore a preliminary account, including petrography, field relations and some geochemistry, and more information will become available during subsequent field seasons.

The country gneisses into which the diorite and its associated dyke fringe were emplaced are tentatively correlated with the Amitsoq gneisses of the Godthasbsfjord region

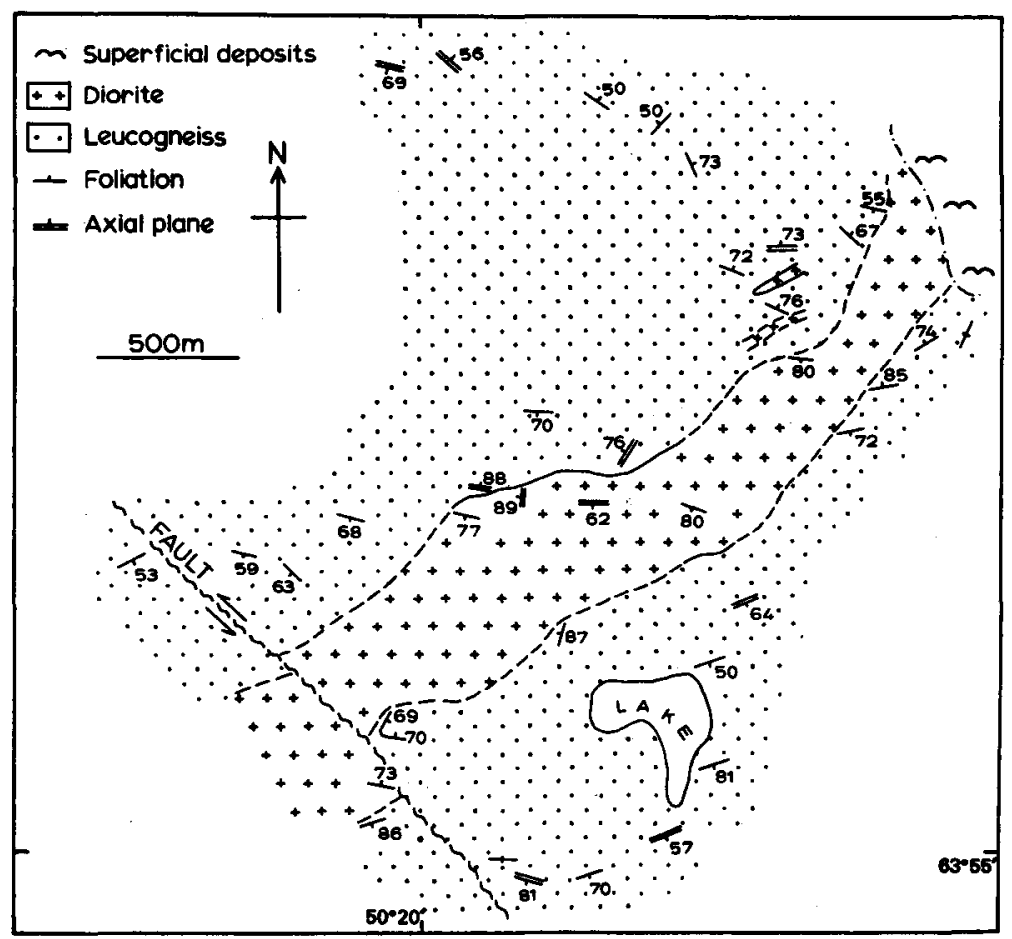

Fig. 35. Sketch map of the diorite body near Kangerdluarssúngûp taserssua. 
(McGregor, 1973) on the basis that the gneisses are cut by clearly recognizable dykes of amphibolite, perhaps belonging to the Ameralik swarm. The gneisses in the region underwent a four-phase deformation sequence as summarized below:

$D_{1}$ development of regional foliation,

$D_{2}$ open to isoclinal folding of foliation,

$\mathrm{D}_{3}$ open to isoclinal folding on steep WNW-ESE axial planes and gentle SE plunging axes.

$\mathrm{D}_{4}$ open to tight folding on steep NNW-SSE axial planes.

Evidence is given below to show that the diorite complex was emplaced after the $D_{1}$ deformation and metamorphism but was involved in subsequent tectonic and metamorphic events.

The diorite complex is clearly an intrusive body. The sheet and its associated dykes strike ENE-WSW across the nearly E-W regional trend of the country gneiss whilst at several localities the actual intrusive contacts are preserved. There the gneissic foliation and concordant pegmatites are truncated, commonly at a high angle, by the pluton or dyke margins and sharply defined xenoliths of gneiss are incorporated into the diorite.

Locally the situation is less clear, however, because acid veins from the gneisses penetrate and agmatise the diorite margins whilst in rare instances the edge of the diorite is invaded by diffuse patches of leucogneiss composition. These very localised features are attributed to 'back-veining' of the diorite by the acid country rocks due to restricted mobilization during emplacement or later metamorphism.

\section{Petrography}

Much of the main body and many of the dykes are dioritic in composition, comprising mainly plagioclase, clinopyroxene and biotite with small amounts of quartz, apatite, sphene, ilmenite and zircon; hypersthene occurs in one sample. Hornblende is typically present, as an alteration product of the clinopyroxene, whilst sphene has developed from ilmenite. Modal analyses of six samples are given in Table 10 from which the considerable range in composition is seen. The rocks are dark, with colour indices ranging from 23.4 to 66.1, although most samples are close to 50 .

The diorites, where unaffected by later deformation, have a distinctive reticulated fabric (fig. 36) composed of randomly oriented biotites and pyroxenes forming a network in which the plagioclases take an interstitial position. The mafic minerals reach $10 \mathrm{~cm}$ in length in some instances but generally are less than $1 \mathrm{~cm}$ in length. The very coarse and fine grained varieties pass abruptly into one another or via intermediate grain sizes. No systematic arrangement of grain-sizes has been detected within the sheet.

In thin section the main fabric comprises an equigranular intergrowth of plagioclase, clinopyroxene and biotite, the mafic minerals together with ilmenite, sphene and apatite tending to form discrete clusters.

Plagioclase, usually in a polygonal fabric, varies from calcic oligoclase (An 22$)$ to sodic labradorite (Anss) although the majority are in the andesine range. Biotite is a pale to deep brown variety forming randomly oriented flakes in undeformed parts of the sheet. The pyroxenes are sub-idioblastic to xenoblastic and commonly are poikiloblastic to any of the other minerals. Clinopyroxene is a colourless to pale green variety, tentatively identified as diopside whilst the hypersthene shows its typical pale green-pale pink pleochroism. 
Table 10. Modal analyses of some diorites and monzodiorites

\begin{tabular}{|c|c|c|c|c|c|c|c|c|c|c|}
\hline & $\begin{array}{l}\text { * } \\
\stackrel{N}{\infty} \\
\infty \\
N \\
\end{array}$ & 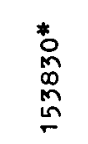 &  & 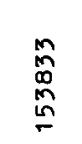 & $\begin{array}{l}\stackrel{+}{D} \\
\stackrel{\infty}{N} \\
\stackrel{n}{n}\end{array}$ & $\begin{array}{l}\stackrel{*}{*} \\
\stackrel{5}{\Phi} \\
\stackrel{N}{N} \\
\stackrel{n}{\sim}\end{array}$ & 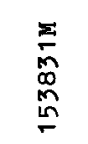 & 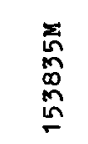 & 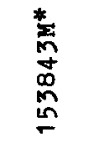 & $\begin{array}{l}\stackrel{p}{0} \\
\stackrel{n}{0} \\
\stackrel{N}{N} \\
\stackrel{n}{\sigma}\end{array}$ \\
\hline Quartz & 0.13 & - & - & - & - & - & - & - & 2.7 & 2.8 \\
\hline Plagioclase & 49.3 & 48.9 & 33.9 & 43.6 & 54.6 & 76.2 & 62.8 & 71.8 & 38.5 & 0.7 \\
\hline K-feldspar & - & - & - & - & - & - & 3.0 & 9.2 & 7.8 & 50.9 \\
\hline Biotite & 30.4 & 34.4 & 22.4 & 24.8 & 34.4 & 16.2 & 25.4 & 14.4 & 35.9 & 2.3 \\
\hline Hornblende & 1.4 & 6.9 & 32.4 & 19.9 & 0.9 & $\operatorname{tr}$ & 2.7 & 0.3 & 7.5 & 14.3 \\
\hline Clinopyrozene & 13.9 & 4.9 & 10.5 & 9.8 & 6.2 & 5.8 & 2.1 & 2.4 & 4.7 & \\
\hline Orthopyroxene & - & - & - & - & - & - & - & - & - & $\{21.5$ \\
\hline Sphene & 3.1 & 3.5 & - & $\operatorname{tr}$ & 2.8 & $\operatorname{tr}$ & 2.1 & 1.5 & 2.4 & 0.5 \\
\hline Zircon & - & - & - & - & - & - & - & - & $\operatorname{tr}$ & - \\
\hline Calcite & - & tr & - & $\operatorname{tr}$ & tr & - & - & - & - & - \\
\hline Apatite & 0.13 & 0.6 & - & 0.6 & 0.9 & 0.3 & 0.4 & $t r$ & 0.4 & 4.5 \\
\hline Opaque minerals & 1.8 & 0.6 & 0.8 & 1.2 & $\operatorname{tr}$ & 1.4 & 1.4 & $\operatorname{tr}$ & $\operatorname{tr}$ & 2.3 \\
\hline C.I. & 51.0 & 50.2 & 66.1 & 55.7 & 44.3 & 23.4 & 33.6 & 18.6 & 50.5 & 40.9 \\
\hline
\end{tabular}

* Chemical analysis in Table 11

M Monzodiorite

$\checkmark$ Leucocratic vein 


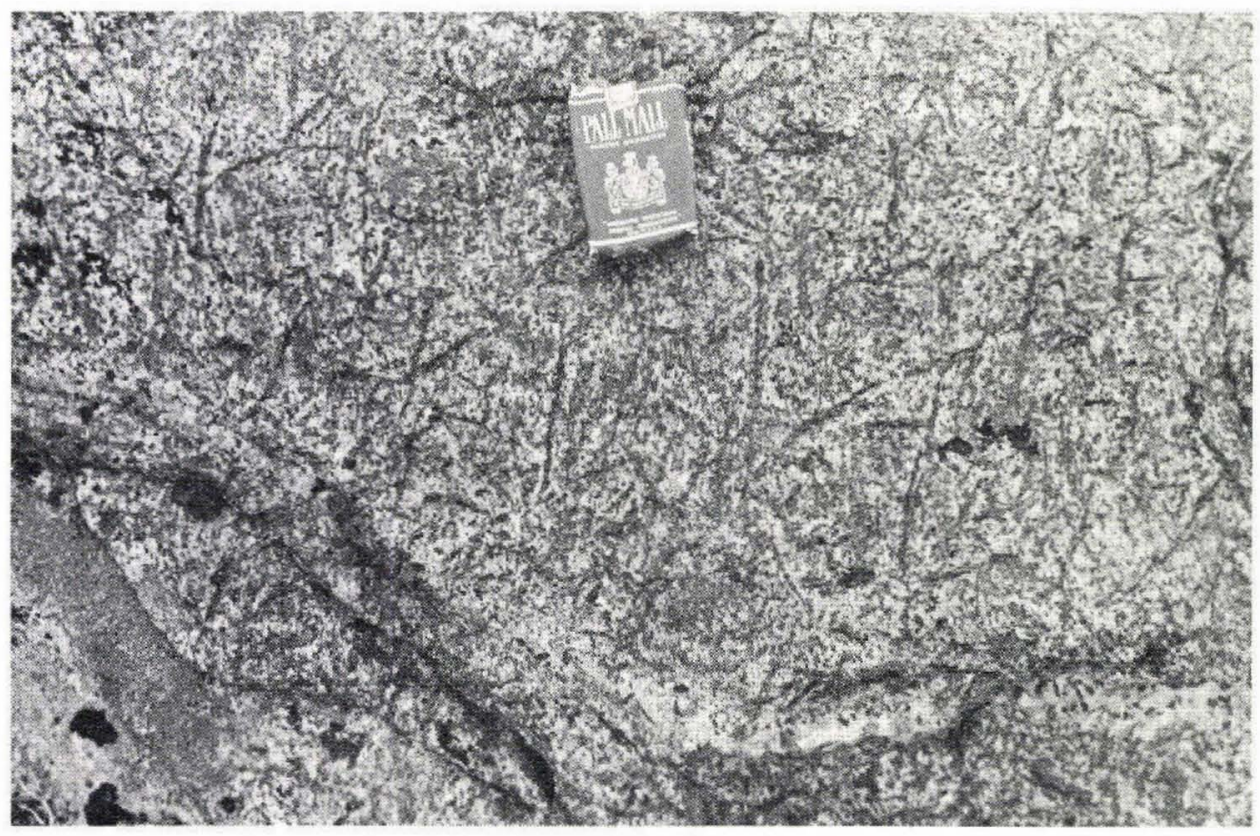

Fig. 36. Reticulated fabric of biotites and pyroxenes in very coarse diorite.

The diorites invariably show some signs of alteration and in places this is strongly developed, though the visible effects are confined to the pyroxenes and ilmenites. As a result of incipient alteration the clinopyroxenes are rimmed by green amphibole aggregates and fine blebs of quartz whilst in more advanced stages the pyroxene cores are also partly replaced by amphibole and dusted by opaque material. The ilmenites are partially altered to give coronas of sphene during this same event although sphene granules also occur in almost fresh diorites and probably developed at an early stage in the evolution of these rocks. Calcite appears in several altered samples, as large poikiloblasts enclosing biotite flakes. It is not clear if this carbonate crystallized with the hornblende and sphene coronas or at an earlier stage.

Monzodiorite is found among the diorites of the main body and also forms one of the dykes. It closely resembles the diorites in mineralogy, texture and alteration and differs only in that it contains a low percentage of K-feldspar among the plagioclase (samples $153831,-35,-43$, Table 10), as microcline, microcline microperthite or microperthite exsolved from antiperthitic plagioclase. In some instances the K-feldspars form larger porphyroblasts. In general the colour indices of the monzodiorites are lower than those of the diorites, ranging from 18.6 to 50.5 .

In the main body the monzodiorite forms narrow sheets in abrupt contact with diorite or as irregular patches with diffuse margins. No systematic study has been attempted on the relationship between the diorites and monzodiorites although on present evidence they are regarded as products of multiple intrusion. 


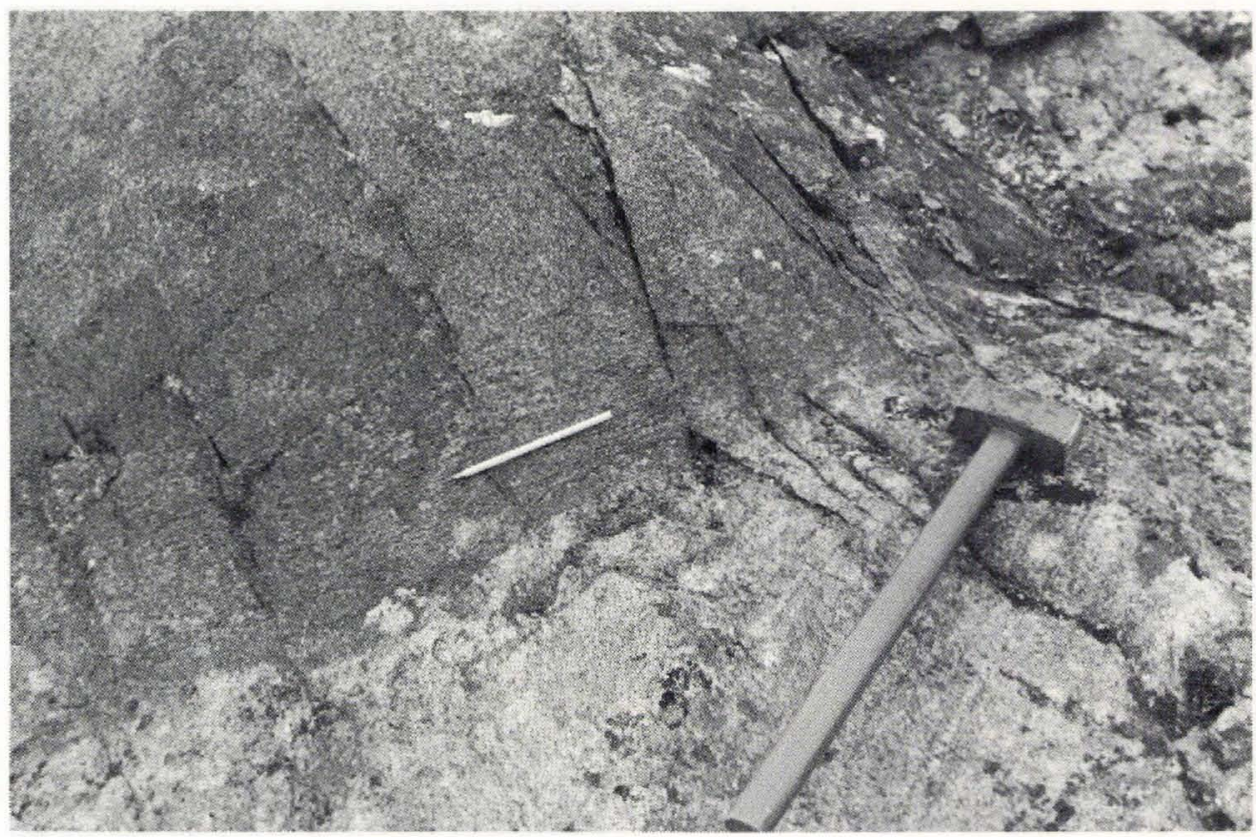

Fig. 37. Dark diorite cross-cutting light leucogneiss. Diorite margin strongly foliated parallel to pencil, leucogneiss foliation parallel to hammer.

\section{Leucocratic veins}

Several narrow $(5-10 \mathrm{~cm})$ sheets of syenitic composition are found in the diorite body and are clearly related genetically to it as they have not been found elsewhere in the region. They comprise coarse pale green clinopyroxene, partly altered to green amphibole and quartz, microcline microperthite and quartz with small amounts of apatite, ilmenite and biotite with traces of sphene and plagioclase (sample 153836, Table 10). Hypersthene appears in the cores of some clinopyroxenes, apparently as relics of larger grains which have been extensively replaced by the diopside.

\section{Internal}

\section{Structural relationships}

A foliation produced by alignment of mafic minerals is widespread in both the main sheet and the dykes and throughout the smaller dykes. In marginal zones this fabric lies sensibly parallel to the contacts of the sheets against the country gneisses (fig. 37).

The syenitic veins described above are deformed into open to isoclinal folds to which the foliation is axial planar (fig. 38). In the folded veins the foliation is strongly defined by aligned pyroxene (- hornblende) prisms and microcline porphyroblasts and typically has a fanning arrangement with respect to axial planes (fig. 39).

Although the foliation and vein-fold axial planes lie parallel to the contacts of the sheets in the marginal zones there is in fact a wide range of orientation of these planes 


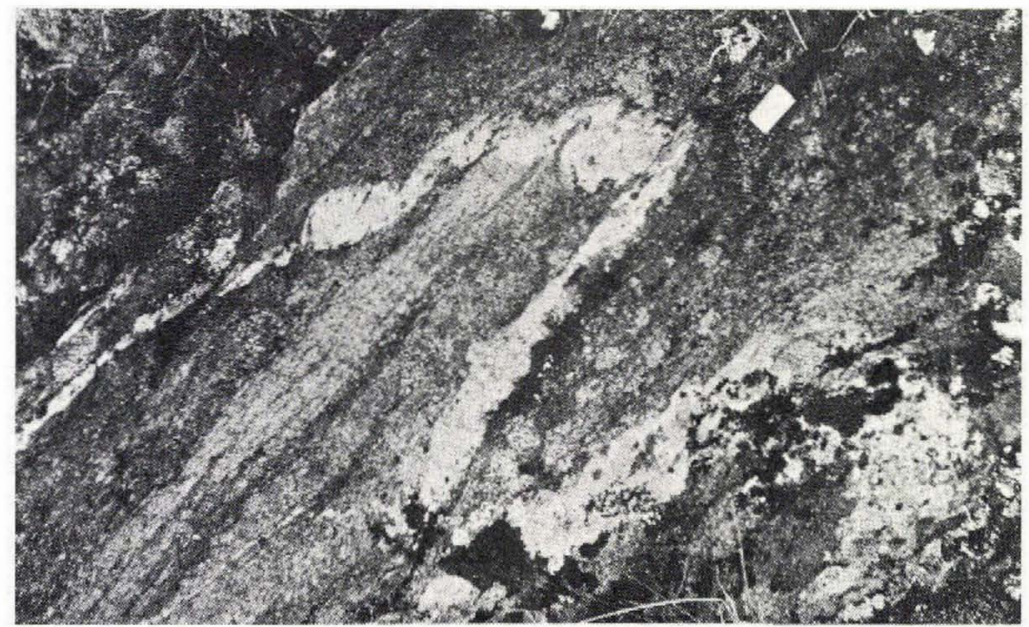

Fig. 38. Folded acid sheet. Foliation in diorite axial planar to these folds.

throughout the main body and dykes despite the nearly constant regional NE-SW trend of the bodies.

It is considered that the axial planes and foliations belong to a single episode of deformation. These planes originally trended NE-SW, parallel to the main sheet and dykes, but were subsequently deformed on NNW-SSE axial planes. There is no direct evidence for these later folds, however, although they are relatively widespread in the country gneisses where they are attributed to the $\mathrm{D}_{4}$ deformation (see below).

\section{External}

The diorite sheets are seen to cross-cut the regional foliation in the country gneisses at several localities. They enclose angular xenoliths of foliated country gneiss and are trans-

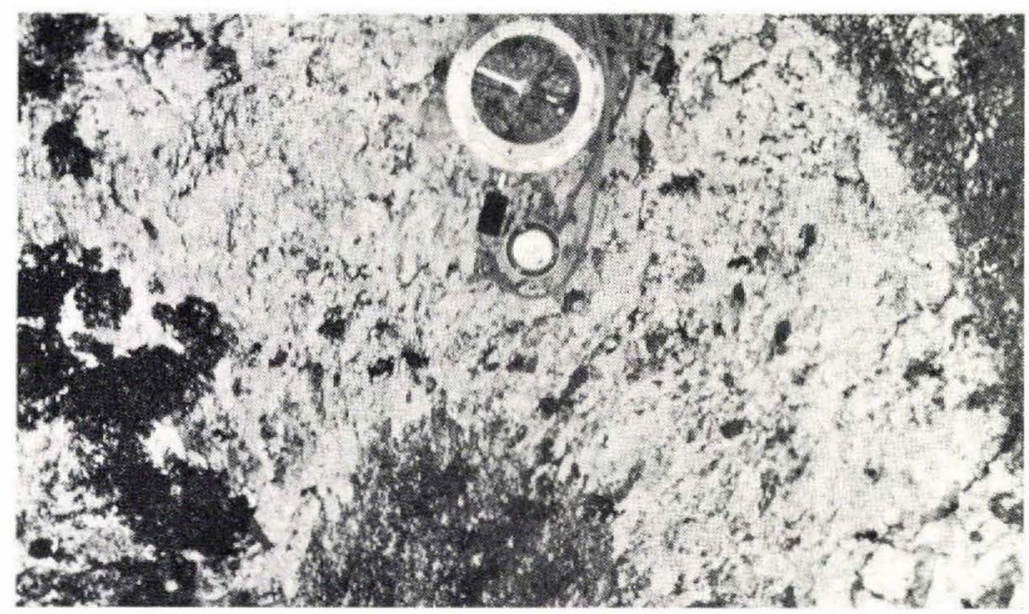

Fig. 39. Fanning foliation in hinge of folded acid sheet. 
gressive on a regional scale. It is, therefore, clear that the diorites were emplaced after the regional $D_{1}$ deformation. In a few localities they also appear to cross-cut folds of the $D_{1}$ foliation, though the angle between the contact (and hence the diorite foliation) is very acute and in some cases sensibly parallel. Interpretation of this situation is uncertain. The folds are either $D_{2}$ or $D_{3}$ in the regional strain sequence but unless the two generations are seen to interfere with each other they are indistinguishable because they are virtually co-axial and coplanar in most areas. One possibility, therefore, is that the diorites post-date the $\mathrm{D}_{2}-\mathrm{D}_{3}$ deformations. However, in view of the near parallelism of the diorite foliation and the axial planes of these folds an alternative interpretation is that the country rock folds and the diorite foliation are cogenetic, i.e., the diorite foliation is either $D_{2}$ or $D_{3}$. The only evidence to help resolve this problem is the presence of a single small-scale fold of the diorite foliation. This has a steep NNE-SSW axial plane and is, therefore, unrelated to the $\mathrm{D}_{4}$ folds. Probably this is a $\mathrm{D}_{3}$ structure re-oriented by $\mathrm{D}_{4}$ and since it deforms the diorite foliation this planar fabric is earlier, i.e., $D_{2}$.

\section{Metamorphic history}

The leucocratic veins in the diorite (see above) provide useful information regarding the metamorphic history of this body. The clinopyroxenes, with amphibole-quartz mantles, are strongly aligned in the axial planes of folds and, therefore, parallel to the diorite foliation. It is considered that the clinopyroxenes crystallized or recrystallized during this $\mathrm{D}_{2}$ deformation, implying that $\mathrm{D}_{2}$ deformation was accompanied by metamorphism of sufficiently high grade for diopside to be stable, that is, in the amphibolite facies. It is unlikely that pre-existing diopsides would have survived as single large grains during deformation under lower temperatures.

It is not clear if the hypersthene relics in the cores of some diopsides crystallized at this stage, that is, under granulite facies, or whether the diopside replaced it then.

Evidently the main diorite body was affected by this same metamorphism and the various mineral components crystallized or recrystallized during this $\mathrm{D}_{2}$ deformation. This is clearly illustrated by the biotites which are strongly aligned in the foliation in many places.

The amphibole-quartz and sphene coronas probably developed during the later stages of this event. The degree and distribution of alteration is too inhomogeneous for it to be attributed to a subsequent regional metamorphism and is more consistent with the patchy development of the $\mathrm{D}_{2}$ fabric in the diorites.

The isotropic reticulated fabric characteristic of the unfoliated diorites probably represents the original, pre- $\mathrm{D}_{2}$ igneous fabric modified to only a limited extent by amphibolite facies static metamorphism in stress-free areas during the $\mathrm{D}_{2}$ deformation. It is not clear, however, to what extent the original mineralogy has been modified.

\section{Geochemical aspects}

As will be appreciated from the petrological descriptions of these rocks the mineralogical composition of the diorites closely resembles that of the amphibolite sheets widely developed in the Fiskenæsset region. In order to see if the diorites and amphibolites are significantly different, chemical analyses of eight diorites and monzodiorites have been made and compared with five amphibolites from the same region. The amphibolite samples were selected on the basis of texture, colour index and mineralogy, to cover as wide a 
Table 11. Geochemical analyses of amphibolites and diorites/monzodiorites

\begin{tabular}{|c|c|c|c|c|c|c|c|c|c|c|c|c|c|}
\hline & $\begin{array}{l}\stackrel{0}{j} \\
\stackrel{j}{n} \\
\stackrel{n}{n}\end{array}$ & $\begin{array}{l}\infty \\
o \\
o \\
n \\
\stackrel{n}{n}\end{array}$ & $\underset{n}{\stackrel{N}{\sigma}}$ & $\begin{array}{l}\infty \\
\text { m } \\
m \\
\text { in }\end{array}$ &  & $\begin{array}{l}\stackrel{\circ}{m} \\
\infty \\
m \\
m\end{array}$ & $\begin{array}{l}\infty \\
m \\
\infty \\
\stackrel{m}{m} \\
\stackrel{n}{n}\end{array}$ & $\begin{array}{l}a \\
m \\
\infty \\
m \\
m \\
n\end{array}$ & $\begin{array}{l}\text { a } \\
\tilde{N} \\
\infty \\
\stackrel{n}{n}\end{array}$ & 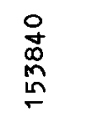 & $\begin{array}{l}\text { nn } \\
\infty \\
\infty \\
i n \\
i\end{array}$ & $\begin{array}{l}n \\
m \\
\infty \\
m \\
m \\
r\end{array}$ & $\begin{array}{l}m \\
\dot{m} \\
m \\
i n \\
r\end{array}$ \\
\hline & 1 & 2 & 3 & 4 & 5 & 6 & 7 & 8 & 9 & 10 & 11 & 12 & 13 \\
\hline & & & & & & & & & & (M). & & (M) & $(\mathrm{M})$ \\
\hline $\mathrm{SiO}_{2}$ & 48.2 & 48.3 & 48.4 & 51.3 & 53.7 & 49.2 & 50.4 & 50.7 & 51.5 & 53.4 & 53.4 & 54.0 & 56.4 \\
\hline $\mathrm{TiO}_{2}$ & 0.49 & 0.48 & 0.62 & 1.63 & 0.73 & 2.45 & 1.29 & 2.17 & 2.39 & 1.50 & 2.24 & 1.46 & 1.53 \\
\hline $\mathrm{Al}_{2} \mathrm{O}_{3}$ & $17 \cdot 7$ & 16.3 & $17 \cdot 1$ & 15.4 & 17.8 & 16.2 & 14.7 & 15.8 & 17.9 & 18.5 & 17.9 & 18.5 & 16.4 \\
\hline $\begin{array}{l}\text { Total } \\
\text { Fe }\end{array}$ & $12 \cdot 3$ & $12 \cdot 3$ & 12.1 & 13.2 & 9.06 & 10.4 & 11.5 & 10.7 & 9.06 & 9.35 & 7.87 & 8.93 & 7.93 \\
\hline $\mathrm{CaO}$ & 10.6 & 13.5 & 10.6 & 8.13 & 9.78 & 7.31 & 8.84 & 6.48 & 7.31 & 4.67 & 5.63 & 5.08 & 4.80 \\
\hline $\mathrm{MgO}$ & 9.30 & 9.30 & 10.4 & 6.82 & 5.91 & 8.03 & 6.59 & 6.36 & 5.68 & 3.31 & 4.38 & 3.50 & $4 \cdot 38$ \\
\hline MnO & 0.20 & 0.24 & 0.16 & 0.18 & 0.17 & 0.13 & 0.14 & 0.14 & 0.14 & 0.13 & 0.08 & 0.11 & 0.12 \\
\hline $\mathrm{Na}_{2} \mathrm{O}$ & 2.25 & 1.90 & & 3.55 & 3.70 & 3.50 & 2.55 & 3.30 & 4.00 & 4.05 & 5.30 & 4.35 & 3.60 \\
\hline $\mathrm{K}_{2} \mathrm{O}$ & 0.20 & 0.62 & 0.38 & 1.79 & 0.88 & 3.82 & 1.56 & 2.84 & 2.97 & 5.16 & 2.97 & 4.88 & 4.51 \\
\hline $\mathrm{P}_{2}{ }^{0} 5$ & 0.05 & 0.01 & 0.03 & 0.10 & 0.11 & 0.13 & 0.10 & 0.14 & 0.10 & 0.30 & 0.19 & 0.31 & 0.25 \\
\hline
\end{tabular}

1 - 5 Amphibolites

Analysts: R. Fuge and H. Edwards

6 - 13 Diorites

M Monzodiorite 


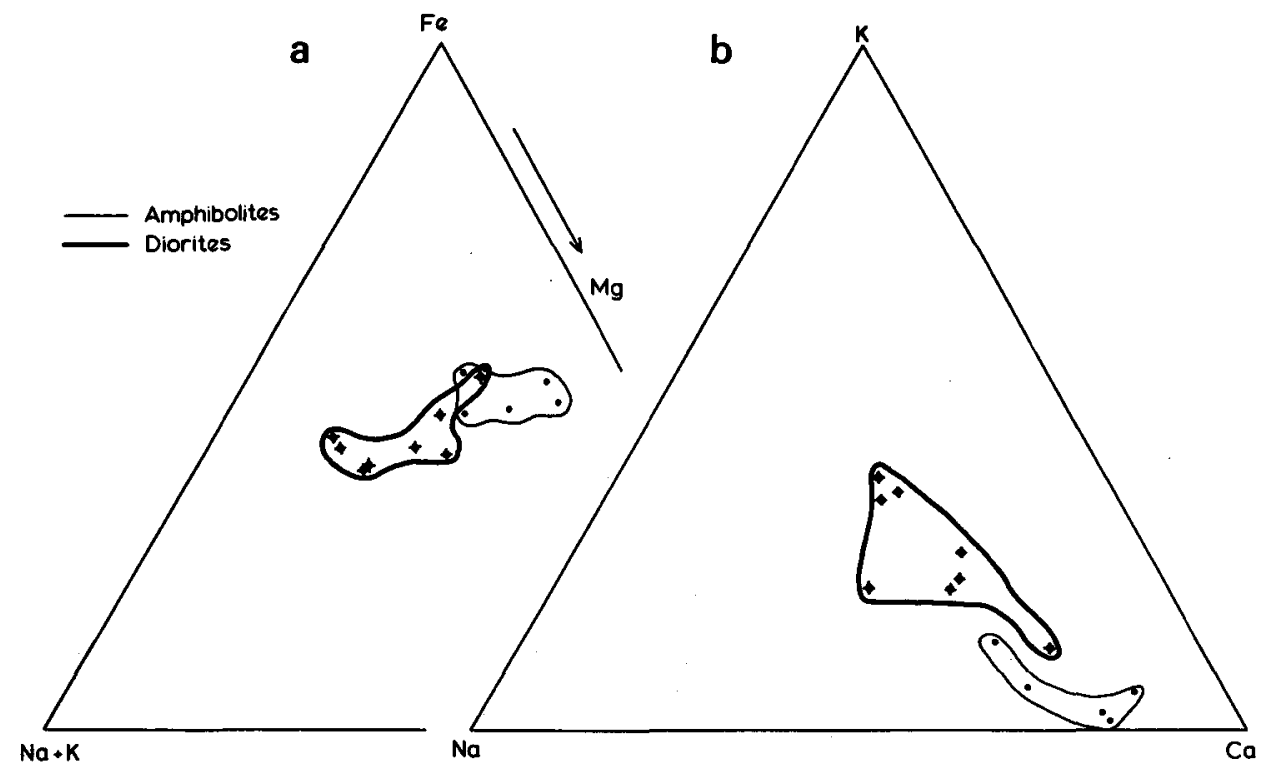

Fig. 40. AFM and Ca-Na-K variation diagrams of the amphibolites and diorites.

range of amphibolite types as possible. The analyses are presented in Table 11 and variation diagrams to compare the diorites and amphibolites given as fig. 40 .

These data clearly establish the separate identity of the two rock-types. The diorites and especially the monzodioritic varieties contain substantially higher $\mathrm{SiO}_{2}$ in most cases, although there is some overlap, and higher $\mathrm{TiO}_{2}$ (usually $>2 \%$ in contrast to usually $<1 \%$ ) (Table 11). The diorites contain less $\mathrm{CaO}$ but substantially higher $\mathrm{Na}_{2} \mathrm{O}$ and $\mathrm{K}_{2} \mathrm{O}$, especially in the case of the monzodiorites (fig. 40b) whilst total Fe is significantly lower (fig. 40a).

\section{Relationship of the diorites to other basic rocks}

The chemical data above have clearly established the separate identity of the diorites and amphibolites from the same region. In this respect it is worth noting that on the AFM and $\mathrm{Ca}-\mathrm{Na}-\mathrm{K}$ variation diagrams there is no significant overlap of the two rock types suggesting that a genetic link is unlikely. However, the position of the amphibolite sheets in the history of this region is not yet understood and it is not possible to confirm whether or not the amphibolites and diorites are separated in time.

Transgressive amphibolite dykes, tentatively regarded as Ameralik dykes, have been identified in several parts of the region. These cut the gneissic foliation of the country rocks and are, therefore, like the diorite body, post-D. However, it has not yet proved possible to determine precisely the position of the amphibolite dykes in the deformation sequence, so that the mutual age relations of the amphibolite dykes and the diorite complex are unknown.

\section{Reference}

McGregor, V. R. 1973: Early Precambrian gneisses of the Godthåb district, West Greenland. Phil. Trans. R. Soc. Lond. A, 273, 343-358. 